\title{
PREVALENCE OF PARASITIC INFESTATION IN CHILDREN OF A RURAL COMMUNITY OF PESHAWAR
}

\section{Jamila Haider', Nabila Sher Mohammad', Rubina Nazli ${ }^{3 凶}$, Sadia Fatima ${ }^{4}$, Tasleem Akhtar}

\begin{abstract}
OBJECTIVE: To find out the actual prevalence of parasitic infestations in a community village Budhni of Peshawar, Pakistan.

METHODS: This cross-sectional study was carried out in village Budhni near Peshawar, Pakistan. A sample of 288 children, aged $<5$ years were randomly selected. Information was collected on the age, gender, feeding and hygiene habits of the mothers and children. Fresh stool sample were collected in sterile bottles for microscopic examination. Data was analyzed statistically using SPSS version 16.
\end{abstract}

RESULTS: A total of 288 children were included in the study; out of which

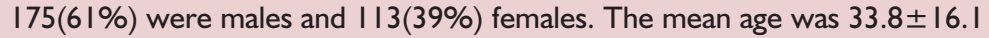
months. An overall prevalence of parasitic infestations was $41 \%(n=117)$. The most common parasites observed were Giardia lamblia $(n=56 ; 19.4 \%)$, Entamoeba histolytica $(n=36 ; 12.5 \%)$ and Hymenolepis nana $(n=18 ; 6.3 \%)$. Multiple infestations were seen in $19 \%$ children. Worm infestation was found more common up to the age of 36 months. Female children were more infected $(n=43 ; 38 \%)$ as compared to male children $(n=55 ; 31.4 \%)$. Worm infestation increased with the family size, low parental education, non-breast fed, use of drinking water from well and lack of toilet facility. Hand washing practice before feeding/weaning and use of soother by the child have also showed some increased frequency of worm infestation.

CONCLUSION: Prevalence of parasitic infestation is quite high in children, aged $<5$ years in rural areas of Peshawar. Single as well multiple infestations were found. Lack of education, improper sanitation and drinking water facility play the major role in causing infection.

KEY WORDS: Intestinal Diseases, Parasitic (MeSH); Worm infestation (Non$\mathrm{MeSH})$; Multiple infestations (Non-MeSH); Giardia lamblia (MeSH); Entamoeba histolytica (MeSH); Hymenolepis nana (MeSH); Ascaris lumbricoides (MeSH); Hymenolepiasis (MeSH); Parasites (MeSH); Rural Population (MeSH).

THIS ARTICLE MAY BE CITED AS: Haider J, Mohammad NS, Nazli R, Fatima S, Akhtar T. Prevalence of parasitic infestation in children of a rural community of Peshawar. Khyber Med Univ J 20।8; I0(I): I4-I8.

\section{INTRODUCTION}

ntestinal parasitic worms' infestation, which is a serious health problem affects millions of people worldwide majority of them being children.' It is one of the major causes of childhood malnutrition, anaemia, stunted physical and mental growth, psycho-social problems and this along with repeated gastrointestinal and upper respiratory tract infection contributes to high morbidity in children and remains a major cause of high infant and child mortality in our country.

Intestinal parasite infestations are more frequent in children of school age, and they have a tendency to occur more in this age group. Impure water, low socioeconomic state, poor sanitation coupled with low literacy rates of parents particularly the mothers are the main causes of this prevalent malady.' Its
I PhD Scholar, Center of Biotechnology \& Microbiology, University of Peshawar, Peshawar, Pakistan

2 Assistant Professor Biochemistry, Khyber Girls Medical College, Peshawar, Pakistan

$3^{\square}$ Professor of Biochemistry, Institute of Basic Medical Sciences, Khyber Medical University, Peshawar, Pakistan Tel: +92-3215773696 E-mail: drrubinanazli.ibms@kmu.edu.pk

4 Assistant Professor Biochemistry, Institute of Basic Medical Sciences, Khyber Medical University, Peshawar

5 Ex-Scientific Research Officer, PMRC Research Centre, Khyber Medical College, Peshawar, Pakistan

Date Submitted: March 15, 2017

Date Last Revised: February 02, 2018

Date Accepted: February 04, 2018

rate varies from country to country and even different among same country. The estimated worldwide affected people are about 3.5 billion, and about 450 million are ill due to these infections, the bulk being children. ${ }^{2,5,6}$

In other estimation about one quarter of the world's population is infected and about $80 \%$ of all deaths annually are due to infectious and parasitic diseases in developing countries. ${ }^{7}$ The reason behind the high prevalence of these infestations is closely correlated to poverty, poor environmental hygiene and impoverished health services.

The effect of Human Intestinal Pathogenic Parasites (HIPP) are significant on the health of the community. ${ }^{7}$ Few studies are carried out on the prevalence of HIPP in Pakistan and that also are based mostly on hospitalized children or on the school going children. ${ }^{1,8-11}$

Due to absence of specific denominator and results it did not reveal the true prevalence of burden of disease due to parasitic infections in the community and health resources, in cooperation by direct analyzing through health services utilization and the disability-adjusted life years (DALYS) lost. These studies also indicated that majority of intestinal parasitic infections were asymptomatic $^{12,13}$ and they did not consult laboratory that is why the true prevalence could not be reported. The large numbers of subject are the carriers and are serious threat for epidemics but the true prevalence cannot be reported ${ }^{13-17}$ 
TABLE I: DEMOGRAPHIC AND SOCIOECONOMIC CHARACTERISTICS OF STUDY POPULATION $(n=288)$

\begin{tabular}{|c|c|c|c|}
\hline \multicolumn{2}{|c|}{ Characteristics } & \multicolumn{2}{|c|}{ Mean \pm SD } \\
\hline \multicolumn{2}{|l|}{ Age (months) } & \multicolumn{2}{|c|}{$33.88 \pm 16.13$} \\
\hline \multicolumn{2}{|l|}{ Height $(\mathrm{cm})$} & \multicolumn{2}{|c|}{$83.12 \pm 18.37$} \\
\hline \multicolumn{2}{|l|}{ Weight $(\mathrm{kg})$} & \multicolumn{2}{|c|}{$12.39 \pm 8.98$} \\
\hline \multicolumn{2}{|l|}{ Family Size } & \multicolumn{2}{|c|}{$4.63 \pm 2.22$} \\
\hline & Characteristics & $\begin{array}{c}\text { Frequency } \\
(n=288)\end{array}$ & Percentage \\
\hline \multirow{2}{*}{ Gender } & Male & 175 & 60.8 \\
\hline & Female & 113 & 39.2 \\
\hline \multirow{2}{*}{ Parents Education } & Illiterate & 112 & 38.9 \\
\hline & Literate & 176 & 61.1 \\
\hline \multirow{3}{*}{ Monthly Income (PKR) } & $<7000$ & 52 & 18.0 \\
\hline & $7000-10000$ & 129 & 44.8 \\
\hline & $>10000$ & 107 & 37.2 \\
\hline \multirow{2}{*}{ Hand Washing (Mother) } & Yes & 206 & 71.5 \\
\hline & No & 82 & 28.5 \\
\hline \multirow{2}{*}{ Hand Washing (Child) } & Yes & 130 & 45.1 \\
\hline & No & 158 & 54.9 \\
\hline \multirow{2}{*}{ Use of Soother } & Yes & 70 & 24.3 \\
\hline & No & 218 & 75.7 \\
\hline \multirow{4}{*}{ Feeding Practices } & Breast feeding & 91 & 31.6 \\
\hline & Bottle feeding & 36 & 12.5 \\
\hline & Mix feeding & 24 & 8.4 \\
\hline & Self/weaned & 137 & 47.5 \\
\hline \multirow{4}{*}{ Source of Drinking Water } & Community Tape & 37 & 12.8 \\
\hline & Hand pump & 211 & 73.3 \\
\hline & Bore well & 35 & 12.2 \\
\hline & Well with cover & 05 & 1.7 \\
\hline \multirow{5}{*}{ Latrine Facility } & Open field squatting & 26 & 9.0 \\
\hline & Pit or borehole privy & 14 & 4.9 \\
\hline & $\begin{array}{l}\text { Pour flush latrine linked } \\
\text { with street drain }\end{array}$ & 184 & 63.9 \\
\hline & Septic tank & 37 & 12.8 \\
\hline & Surface privy & 27 & 9.4 \\
\hline
\end{tabular}

As limited community-based studies are conducted in Peshawar area regarding prevalence of parasitic infestations in pediatric population, this study was planned to find out the actual prevalence of parasitic infestations in children of less than five years of age in village Budhni of Peshawar, Pakistan.

\section{METHODS}

This cross-sectional study was conducted on children less than five years in village Budhni, the model village by Pakistan Medical Research Council (PMRC) for its research studies. It is about 30 KM away from Peshawar and has population of 10,147 and total houses 1549. For research purpose the whole village is divided into 9 geographical blocks and each house is marked with a specific number. Family folder of each family is maintained and updated regularly. The population of children under five is approximately 87 I in this village. The study was approved from the ethical committee of Postgraduate Medical Institute (PGMI), Peshawar. About 288 children of aged $<5$ years of either sex were selected randomly in the study by using the formula $N=4 Z \alpha^{2} P(I-P) \div W^{2}$ for sample with prevalence rate at $25 \%$ level. The nature and procedure of the study was explained to the parents and informed consent taken. The mother/ proxy of child were interviewed by a trained health care worker according to pre-designed questionnaire. The demographic variables age, gender, education/socioeconomic status of the parents, source of drinking water and sanitary condition of the household were recorded. Feeding practices of child whether breast feeding or bottle feeding and use of soother were also recorded. Weight and height of child were measured according to standard methods. Our study inclusion criteria were children under 5 years of age of both genders either having symptoms of parasitic infestation or asymptomatic with no present history of antidiarrheal drugs and dysentery treatment. Children having any type of infection or active disease were excluded from our study.

A plastic vial with a spoon and sterile tight-fitting lid was given to the mother of child for collection of stool specimen during house to house visit. The mother was instructed to avoid stool contamination with urine. Each container was marked with waterproof ink with an identification number. Fresh stool samples were delivered to lab immediately for microscopy and other examinations.

To achieve reliable results a mini lab was established in the Community Research Centre in village Budhni equipped with basic requirements. All stool specimens were examined fresh with microscopy being done for intestinal parasites. Different risk factors associated with intestinal parasites were also calculated at a significance level of $P<0.05$. Data was analyzed statistically using SPSS version 16.

\section{RESULTS}

Socio-demographic and socioeconomic characteristics of study population are shown in Table I. A total of 288 children

TABLE II: TYPE OF PARASITES PRESENT IN THE STUDY POPULATION ON MICROSCOPIC EXAMINATION

\begin{tabular}{|l|c|c|}
\hline Type of Parasite & $\begin{array}{c}\text { Frequency } \\
(\mathbf{n = 2 8 8})\end{array}$ & Percentage \\
\hline Giardia lamblia & 56 & 19.4 \\
\hline Entamoeba histolytica & 36 & 12.5 \\
\hline Hymenolepis nana & 18 & 6.3 \\
\hline Ascaris lumbricoides & 06 & 2.1 \\
\hline Trichuris trichiura & 01 & 0.3 \\
\hline
\end{tabular}


TABLE III: DIFFERENT TYPES OF PARASITES FOUND IN COMBINATION ON MICROSCOPIC EXAMINATION OF STOOL SPECIMEN

\begin{tabular}{|l|c|c|}
\hline Type & $\begin{array}{c}\text { Frequency } \\
(\mathbf{n = 1 9 )}\end{array}$ & Percentage \\
\hline Giardia lamblia \& Hymenolepis nana & 9 & 47.3 \\
\hline Giardia lamblia \& Entamoeba histolytica & 6 & 31.6 \\
\hline Entamoeba histolytica \& Hymenolepis nana & 2 & 10.5 \\
\hline Giardia lamblia \& Ascaris lumbricoides & $\mathrm{I}$ & 5.3 \\
\hline Ascaris lumbricoides \& Hymenolepis nana & $\mathrm{I}$ & 5.3 \\
\hline Total & $\mathbf{1 9}$ & $\mathbf{1 0 0}$ \\
\hline
\end{tabular}

were included in the study; out of which I 75 (6I\%) were males and II $3(39 \%)$ females. The mean age was $33.8 \pm 16.1$ months.

Mean family income of $44.8 \%$ families ranged between Rs. 7,000-10,000. About II 2 (39\%) parents were illiterate. Hand washing before feeding/ weaning was practiced by 206 (7I.5\%) mothers and 130 (45\%) children. Soother was used by 70 (24\%) children. Only 91 (31.6\%) children were breast fed. Main source of drinking water was hand pump in $21 \mathrm{I}(73 \%)$ and flush latrine was present in 184 (64\%) houses.

Different types of intestinal parasites identified on stool microscopy are shown in Table II. An overall prevalence of parasitic infestation was 98/288 (34\%). The most common parasite was Giardia lamblia found in 56 (19.4\%) stool specimens followed by Entamoeba histolytica in 36 (12.5\%) cases. More than one parasite was seen in $19 \%$ children (Table III).

Distribution of parasites on microscopy according to age and gender is shown in Table IV. Infestation increased with age of the child up to 36 months. Most infected cases were between the age group of 25-36 months.

Factors related to worm infestation are shown in Table V. Female children were somehow more infected $(n=43 ; 38 \%)$ as compared to male children $(n=55$; $31.4 \%$ ). Worm infestation increased with the family size and maximum II
(42.3\%) infected children belonged to families having $>7$ family members. It was observed that higher parental education was associated with lower frequency of worm infestation and worm infestation was highest in children whose parents were illiterate. No much difference in frequency of worm infestation was seen in mother/child hand washing practice before feeding/weaning or use of soother by the child. Hand pumps were the major source of drinking water in this community; almost 77 (36.5\%) children were infected with the parasites using water from this source. Worm infestation was more $(60 \%)$ in children using water from a well as compared to those using it from the community tap $(24.3 \%)$. A significant $(P<0.02)$ number of non-breast fed children 76 (38.6\%) were infected with parasites as compared to those who were breast fed 22 (24.2\%). Toilet facility showed a direct relation to parasitic infection and $12(46.2 \%)$ children were found infected when latrine facility was not available in the house hold and they used open fields for squatting. Although these risk factors were affecting the frequency of intestinal parasites to certain extent but none except breast feeding could attain the level of significance.

\section{DISCUSSION}

In the present study, parasites were present in $40.6 \%$ samples; this is similar to many studies where the prevalence ranges from $30 \%$ to $80 \%$. Poor living conditions could be the cause of high prevalence along with using of unsafe water, poor sanitary conditions and improper disposal of waste. These factors were reported by other authors as well along with a climatic difference and temperature and humidity. 18,19

The parasitic infestation was more common in females while this difference was non-significant in other studies. Controversies exist in studies regarding gender and parasitic infestation.'

Parasitic infestation was mostly seen between 25-36 months (53.9\%). A study from Abbottabad showed 2-5 years as the most common age group as in this age the child starts walking and playing with soil. ${ }^{20}$ WHO has recommended that every child between 2 to 5 years should be given single dose of anthelminthic drug (prophylactic dose) every 6 monthly (Integrated Management of Childhood Illness). ${ }^{18}$

In this study the most common parasite was Giardia Lamblia (19.4\%), followed by Entamoeba Histolytica, a protozoan and Hymenolepis nana, a helminthes. Similar results were reported from Karachi. ${ }^{21}$ Hook worm was not observed in our study and in other studies. ${ }^{20}$ Similarly pin worm (Enterobius Vermicularis) which is common in this part of the world was not found in this study. Different combinations of helminthes and protozoa are reported in other studies. ${ }^{22}$

Ratio of protozoal (78.6\%) to helminthic (21.4\%) infection in present study was 3.7: I, which is similar to $3.5: 1$ reported from Karachi. ${ }^{21}$

A study conducted at Quetta ${ }^{22}$ showed an overall lower prevalence of paristosis $(31 \%)$ as well multiple infestation (I8\%) same as in our study. The frequency of parasites found were in

TABLE IV: DISTRIBUTION OF PARASITES POSITIVE CHILDREN ON MICROSCOPIC EXAMINATION OF STOOL SPECIMENS ACCORDING TO AGE AND GENDER

\begin{tabular}{|c|c|c|c|c|c|c|}
\hline \multirow{3}{*}{ Age (months) } & \multicolumn{6}{|c|}{ Parasite positive } \\
\hline & \multicolumn{2}{|c|}{ Male $(n=55)$} & \multicolumn{2}{|c|}{ Female $(n=43)$} & \multicolumn{2}{|c|}{ Total $(n=98)$} \\
\hline & Frequency & Percentage & Frequency & Percentage & Frequency & Percentage \\
\hline $0-12$ & 05 & 9 & 01 & 2.3 & 6 & 6.0 \\
\hline $13-24$ & 12 & 22 & 09 & 20.9 & 21 & 21.4 \\
\hline $25-36$ & 16 & 29 & 18 & 41.9 & 34 & 34.8 \\
\hline $37-48$ & 11 & 20 & 05 & 11.6 & 16 & 16.4 \\
\hline $49-60$ & 11 & 20 & 10 & 23.3 & 21 & 21.4 \\
\hline
\end{tabular}




\begin{tabular}{|c|c|c|c|c|c|}
\hline \multirow{2}{*}{\multicolumn{2}{|c|}{ Factors }} & \multirow{3}{*}{$\begin{array}{c}\begin{array}{c}\text { Total } \\
(\mathrm{n}=\mathbf{2 8 8})\end{array} \\
175 \\
\end{array}$} & \multicolumn{2}{|c|}{ Parasite Positive } & \multirow{3}{*}{$\frac{\mathrm{p} \text {-value }}{-}$} \\
\hline & & & Frequency & Percentage & \\
\hline \multirow{2}{*}{ Gender } & Male & & 55 & 31.4 & \\
\hline & Female & 113 & 43 & 38.0 & 0.3 \\
\hline \multirow{3}{*}{ Family Size } & $<4$ & 140 & 41 & 29.3 & - \\
\hline & $5-7$ & 122 & 46 & 37.7 & 0.18 \\
\hline & $>7$ & 26 & 11 & 42.3 & 0.27 \\
\hline \multirow{4}{*}{ Parents Education } & Illiterate & 112 & 44 & 39.3 & - \\
\hline & Secondary & 107 & 35 & 32.7 & 0.38 \\
\hline & Higher Secondary & 17 & 5 & 29.4 & - \\
\hline & Graduation \& higher & 52 & 14 & 26.9 & 0.17 \\
\hline \multirow{3}{*}{$\begin{array}{l}\text { Family Income } \\
\text { (PKR) }\end{array}$} & $<7000$ & 116 & 37 & 31.9 & - \\
\hline & $7000-10000$ & 43 & 12 & 27.9 & 0.77 \\
\hline & $>10000$ & 129 & 49 & 37.9 & 0.39 \\
\hline \multirow{2}{*}{$\begin{array}{l}\text { Washing Hands for } \\
\text { Feeding (Mother) }\end{array}$} & Yes & 206 & 68 & 33 & 0.7 \\
\hline & No & 82 & 30 & 36.6 & - \\
\hline \multirow{2}{*}{$\begin{array}{l}\text { Washing Hands } \\
\text { Before Meal (Child) }\end{array}$} & Yes & 130 & 48 & 36.9 & - \\
\hline & No & 158 & 43 & 27.2 & - \\
\hline \multirow{2}{*}{ Use of Soother } & Yes & 70 & 22 & 31.4 & 0.70 \\
\hline & No & 218 & 76 & 34.9 & - \\
\hline \multirow{4}{*}{$\begin{array}{l}\text { Source of Drinking } \\
\text { Water }\end{array}$} & Community tape & 37 & 9 & 24.3 & - \\
\hline & Hand pump & 211 & 77 & 36.5 & 0.21 \\
\hline & Tube well & 35 & 9 & 25.7 & 0.83 \\
\hline & Well (house) & 5 & 3 & 60 & 0.25 \\
\hline \multirow{4}{*}{ Mode of Feeding } & Bottle feeding & 36 & 10 & 27.8 & - \\
\hline & Breast feeding & 91 & 22 & 24.2 & 0.84 \\
\hline & Mix feeding & 24 & 6 & 25 & 0.95 \\
\hline & Self/weaned & 137 & 60 & 43.8 & 0.85 \\
\hline \multirow{2}{*}{ Breast feeding } & Yes & 91 & 22 & 24.2 & \multirow{2}{*}{0.02} \\
\hline & No & 197 & 76 & 38.6 & \\
\hline \multirow{5}{*}{ Latrine Facility } & Open field squatting & 26 & 12 & 46.2 & - \\
\hline & Pit or borehole privy & 14 & 2 & 12.3 & 0.09 \\
\hline & Pour flush latrine & 184 & 63 & 34.2 & 0.33 \\
\hline & Septic tank & 37 & 14 & 17.8 & 0.68 \\
\hline & Surface privy & 27 & 7 & 25.9 & - \\
\hline \multirow{2}{*}{\multicolumn{2}{|c|}{$\begin{array}{l}\text { Open field } \\
\text { Home toilet }\end{array}$}} & 26 & 12 & 46.2 & \multirow{2}{*}{0.24} \\
\hline & & 262 & 86 & 32.8 & \\
\hline
\end{tabular}

order of Hymenolepis nana (34\%), Giardia lamblia (32\%), Entamoeba histolytica (29\%), Ascaris lumbricoides (4\%) Ankylostoma duedenale (1\%), while in our study the order of frequency was Giardia lamblia 56 (19.4\%), Hymenolepis nana 18 (6.3\%) and Ascaris lumbricoides 6 (2.1\%).

A study conducted in Karachi ${ }^{9}$ on children of $\mathrm{I}-5$ years showed an increased prevalence of paristosis (52.8\%). The most frequent parasite found was Giardia lamblia similar to our study. However, the study reported a lower frequency of multiple parasitic infections (10\%). Poor living conditions, use of unsafe water supply, improper disposal of waste and poor sanitary abad 20 I4 Jan-Mar; 26(I):49-5I.

2. Kavathia G, Pattani M, ChaudharyA, Joshi T, Mehta K. A Prevalence Study of Intestinal Parasitic Infections in symptomatic children at Tertiary Care Hospital in Rajkot City of Gujarat (India). IOSR J Dent Med Sci (IOSR-JDMS) 2016 May; I5(5): I3I5. DOI:I0.9790/0853-I50505 I3 I5

3. Faria CP, Zanini GM, Dias GS, da Silva S, de Freitas MB, Almendra R, et al. Geospatial distribution of intestinal parasitic infections in Rio de Janeiro (Brazil) and its association with social determinants. PLoS Negl Trop D is $2017 \mathrm{Mar}$ 8; I I(3):e0005445. DOI: I0.137I/ journal.pntd. 0005445.

4. Shah SA, Zai S, Muhammad A. Correlation of haemoglobin level with intestinal parasites in school children. J Post Med Inst 2006;20(3):232-4.

5. Wegayehu T, Tsalla T, Seifu B, Teklu T. Prevalence of intestinal parasitic infections among highland and lowland dwellers in Gamo area, South Ethiopia. BMC Public Health 2013 Feb I8;।3:I5I. DOI: I0.II86/I47I-2458-I3-I5I.

6. Daryani A, Hosseini-Teshnizi S, Hosseini SA, Ahmadpour E, Sarvi S, Amouei $A$ et al. Intestinal parasitic infections in Iranian preschool and school children: A systematic review and meta-analysis. Acta Trop 20I7 May;169:69-83. DOI: 10.1016/j.actatropica.2017.01.019.

7. Rashid MK, Joshi M, Joshi HS, Fatemi $K$. Prevalence of intestinal parasites among school going children in Bareilly district. Natl J Integr Res Med 20 I I;2(I):35-7.

8. Keiser J, Utzinger J. The drugs we have and the drugs we need against major helminth infections. Adv Parasitol 20I0; 73: 197-230. DOI: 10.1016/S0065-308X(10)73008-6.

9. Mehraj V, Hatcher J, Akhtar S, Rafique G, Beg MA. Prevalence and factors associated with intestinal parasitic infection among children in an urban slum of Karachi. PLoS One 2008; 3 (I I) :e 3680 . DOI: I0.137I/journal.pone. 0003680 . 
10. Ullah I, Sarwar G, Aziz S, Khan MH. Intestinal worm infestation in primary school children in rural Peshawar. Gomal J Med Sci 2009;7(2): 132-6.

I I. Khan W, Nisa NU, Khan A, Naqvi SMHM. Endemicity of intestinal parasites with special reference to nematodes in individuals related to education (students, staff \& workers) in Swat KP, Pakistan. Pak J Nematol 2012;30(I):77-85.

12. Koshak EA, Zakai HA. A spectrum of pathogenic and nonpathogenic intestinal parasites in preemployment medical checkup for workers and their family. J Fam Community Med 2003; I ( (I):47-53.

13. Mohammad KA, Koshak EA. A prospective study on parasites among expatriate workers in AlBaha from 200920 I I, Saudi Arabia. J Egypt Soc Parasitol 20II; 4I(2): 423-443.

14. Pullan RL, Brooker SJ. The global limits and population at risk of soiltransmitted helminth infections in 2010. Parasit Vectors 2012;5:81. DOI: I0.I I86/I756-3305-5-8I.

I5. Kumar H, Jain K, Jain R. A study of prevalence of intestinal worm infestation and efficacy of anthelminthic drugs. Med J Armed Forces India 2014;70(2):I44-8. DOI: I0.1016/j.mjafi.2013.12.009.

16. Taha HA, Soliman MI, Banjar SAN. Intestinal parasitic infections among expatriate workers in Al-Madina AlMunawara, Kingdom of Saudi Arabia. Trop Biomed 20 I 3;30(I):78-88.

17. Samie A, Guerrant RL, Barrett L, Bessong PO, Igumbor EO, Obi CL. Prevalence of intestinal parasitic and bacterial pathogens in diarrhoeal and non diarrhoeal school children at Hail, Saudi Arabia. N Y Sci J 201 I;4(6): 106-I3.

18. World Health Organization (WHO). Integrated Management of Childhood Illness. WHO
Recommendations. [Cited on: March 10, 2017]. Available from URL: www.who.int/violenceprevention/a bout/participants/unicef/en

19. Zaglool DA, Khodari YA, Othman RAM, Farooq MU. Prevalence of intestinal parasites and bacteria among food handlers in a tertiary care hospital. Niger Med J 20II;52(4):266-70. DOI: $10.4103 / 0300-1652.93802$.

20. Ahmed AK, Malik B, Shaheen B, Yasmeen G, Dar JB, Mona AK, et al. Frequency of intestinal parasitic infestation in children of $5-12$ years of age in Abbottabad. J Ayub Med Coll Abbottabad 2003; I 5 (2):28-30.

21. Bilqees FM, Ali MN. Protozoan intestinal infections in Karachi. Pak J Med Res 1981; 20:6-9.

22. Ahsan-ul-Wadood, Bari A, Rhman $A U$, Qasim KF. Frequency of Intestinal Parasite Infestation in Children Hospital Quetta. Pak J Med Res 2005;44(2):87-8.

\section{AUTHOR'S CONTRIBUTION}

Following authors have made substantial contributions to the manuscript as under:

JH, RN: Concept \& study design, analysis \& interpretation of data, drafting the manuscript, final approval of the version to be published

NSM \& SF: Acquisition of data, drafting the manuscript, final approval of the version to be published

TA: Critical review, drafting the manuscript, final approval of the version to be published

Authors agree to be accountable for all aspects of the work in ensuring that questions related to the accuracy or integrity of any part of the work are appropriately investigated and resolved.

This is an Open Access article distributed under the terms of the Creative Commons Attribution-NonCommercial-NoDerivatives 4.0 International License (https://creativecommons.org/licenses/by-nc-nd/4.0/) which permits to reproduce freely in any medium and share the Licensed Material, for NonCommercial purposes only, provided the original work is properly cited. 